\title{
EFFECT OF CHITOSAN COATINGS ON PRESERVATION OF RED SNAPPER (LutjanusargentimaculatusForsskal, 1775 ) DURING LOW TEMPERATURE STORAGE
}

\author{
Heru Pramono $^{\mathrm{a}, *}$, Tri Wahyuni ${ }^{\mathrm{b}}$, Faris Abidin ${ }^{\mathrm{b}}$, Wahyu Andrianto ${ }^{\mathrm{b}}$, dan Farezza Ferdyna Nanda \\ Sumartono ${ }^{\mathrm{b}}$ \\ ${ }^{a}$ Department of Marine, Faculty of Fisheries and Marine, Airlangga University, Campus C UNAIR, \\ Dharmahusada 380 Street, Mulyorejo, Surabaya, Indonesia \\ ${ }^{b}$ Department of Aquaculture, Faculty of Fisheries and Marine, Airlangga University, Campus C UNAIR, \\ Dharmahusada 380 Street, Mulyorejo, Surabaya, Indonesia \\ *Corresponding author : E-mail Address :heru.pramono@fpk.unair.ac.id
}

\begin{abstract}
Abstrak
Pengaruh pelapisan tipis tiga konsentrasi chitosan yang berbeda $(0,1$ dan $2 \% \mathrm{~b} / \mathrm{v})$ terhadap kualitas mikrobiologi (angka lempeng total (ALT)), kualitas kimia ( $\mathrm{pH}$ dan total volatile basic-nitrogen (TVB-N)), dan karakteristik sensorik ikan kakap merah (Lutjanus argentimaculatus Forsskal, 1775) selama penyimpanan dingin $\left(4-7^{\circ} \mathrm{C}\right)$ dievaluasi secara berkala. Kualitas mikrobiologis ikan kakap merah yang dilapisi dengan kitosan lebih rendah dibandingkan kontrol, sedangkan pH dan TVB-N lebih rendah saat mendapatkan perlakuan pelapisan tipis kitosan. Skor keseluruhan evaluasi sensorik ikan dengan lapis tipis kitosan konsentrasi $1 \%$ (b/v) lebih tinggi jika dibandingkan perlakuan yang lain. Studi ini menunjukkan bahwa lapisan tipis kitosan sebelum penyimpanan dan distribusi ikan kakap merah dapat memperpanjang umur simpan ikan segar meskipun kualitas mikrobiologis ikan tergantung pada kualitas awal produk sebelum perlakuan pelapisan tipis kitosan.
\end{abstract}

Kata kunci: Kitosan, Pelapisan Tipis, Penanganan Ikan, Umur simpan

\begin{abstract}
The effect of three different concentration of chitosan $(0,1$ and $2 \% \mathrm{w} / \mathrm{v})$ on microbiological (aerobic plate count), chemicals ( $\mathrm{pH}$ and total volatile basic nitrogen $(T V B-N))$, and sensory properties of red snapper (Lutjanus argentimaculatus Forsskal, 1775) during cold storage $\left(4-7^{\circ} \mathrm{C}\right)$ was evaluated periodically. The microbiological quality of red snapper coated with chitosan was lower compared to the control, whereas $\mathrm{pH}$ and TVB-N were lower when treated with chitosan coating. The overall score of sensory evaluation of chitosan with concentration of $1 \%(w / v)$ was higher compared to remaining treatments. This study indicated that coating of chitosan prior to storage and distribution of red snapper prolong the shelf life of the fish but the microbial quality during storage is depend on initial quality of the fish.
\end{abstract}

Keywords: Chitosan, Coating, Fish handling, Shelf life

\section{INTRODUCTION}

Red snapper (Lutjanus argentimaculatus Forsskal, 1775) is one of the economically important fish species in Indonesia. The quality of fish during storage remains important issues in tropical countries such as Indonesia due to the higher rate of spoilage in the room temperature. Chilling is an effective and efficient method to reduce the rate of deterioration as well as to prolong shelf life of fish [1]. Various methods have been reported which consist of thermal and non-thermal processing. Thermal processing such as pasteurization [2] and canning is commonly applied. However, the eating quality of the products is change due to denaturation of fish protein. Non-thermal processing such as hydrostatic pressure, irradiation, ozonization, and modified atmosphere packaging was developed to overcome the problem. However, the high capital for equipment is needed. Therefore, the simple and cheap method to extend shelf life of fresh fish is needed. 
Chitosan is a natural polymer (poly $(1 \rightarrow 4)$-2-amino-2deoxy-D-glucopyranosyl) obtained from deacetylation of chitin is mainly produced from crustacea shells [3]. Chitosan exhibit antimicrobial activity against wide range of microbes, such as bacteria, yeast and fungi [4]. Due to it non-toxic characteristic, it can be applied as food additive to extend the shelf life of foods. Chitosan can be applied to prolong the shelf life of pacific oysters (Crassostrea gigas) from 8-9 days to 14-15 days during storage under $5^{\circ} \mathrm{C}$ [5]. Application of chitosan with antioxidant to preserve grass carp during cold storage and found outthat chitosan with the addition of acetic acid and tea polyphenol was effective to keep the sensory quality of fish during storage [1]. All of those study used high quality of fish prior to application of chitosan. However, fish is commonly purchased from the markets with various qualities due to transportation and distribution.

During transportation and distribution, fish is treated with the addition of ice, therefore the temperature is not constant. The main objective of this study was to evaluate the microbial, chemical, and sensory quality of red snapper during chilling storage and to confirm the potential of chitosan coating in fresh fish shelf-life.

\section{MATERIAL AND METHOD}

\section{Materials}

Chitosan with degree of deacetylation of $78 \%$ was purchased from Bogor Agriculture University. Glacial acetic acid (Sigma Aldrich, USA) for made dilution of chitosan was p.a. Fish used was purchased from Pabean Market, Surabaya and taken to the laboratory with insulator box with the addition ice $\left(4-7^{\circ} \mathrm{C}\right)$.

\section{Methods}

\section{1) Preparation of Chitosan Solution}

The chitosan solution was prepared with method described by Fan and co-worker [6]. Briefly, for preparing $1 \% \mathrm{w} / \mathrm{w}$ chitosan solution, $10 \mathrm{~g}$ chitosan were mixed with 900 $\mathrm{ml}$ of distilled water and stirred for $10 \mathrm{~min}$ prior to addition of $10 \mathrm{ml}$ of glacial acetic acid. The solution was stirred for $2 \mathrm{~h}$ and added with distilled water up to $1 \mathrm{~L}$. For preparing $2 \% \mathrm{w} / \mathrm{w}$ chitosan solution, $20 \mathrm{~g}$ chitosan were used with the same method described previously.

\section{2) Preparation of Red Snapper Coating}

Fresh red snapper (L. argentimaculatus) with average weight of $200 \mathrm{~g}$ were purchased from wet market of Surabaya. After being gutted and washed, fish samples were dipped in $1 \%$ and $2 \%$ chitosan solution and in $1 \%$ glacial acetic acid as control respectively for 2 $\mathrm{h}$ and then drained. All samples were individually packed in polyethylene bag and stored in insulated box with the addition of ice. Fish samples were taken randomly every 3 days for microbiological, chemicals and sensory evaluation.

\section{3) Microbiological Analysis}

Total viable count (TVC) was determined in plate count agar (PCA, Oxoid) by spread plate method [7].

\section{4) pH and Total Volatile Basic \\ Nitrogen $(T V B-N)$ Analysis}

Determination of $\mathrm{pH}$ was performed by homogenizing $10 \mathrm{~g}$ sample in $100 \mathrm{ml}$ distilled water and the mixture was filtered. The $\mathrm{pH}$ of filtrate was measured by employing digital $\mathrm{pH}$ meter (Labortechnik, Germany).

For Total Volatile Basic-Nitrogen analysis, a total of 10 grams of fish samples were randomly taken and homogenized with $90 \mathrm{~mL}$ perchloric acid $(6 \% \mathrm{v} / \mathrm{v})$. It was followed by centrifugation at $4,000 \times g$ at $4^{\circ} \mathrm{Cfor} 5 \mathrm{~min}$ and the supernatant was distilled with micro distillation unit. The distillate was collected in boric $\operatorname{acid}(3 \% \quad \mathrm{w} / \mathrm{v})$ and titrated with hydrochloric acid $(0.05 \mathrm{~N})$. Results havebeen expressed in $\mathrm{mg}$ of nitrogen per $100 \mathrm{~g}$ of sample [8].

\section{5) Sensory Evaluation}

The sensory quality of fish sample was evaluated by a six member-trained panel from the student. Panelist scored for sensory 
characteristics such as flavor, color, odor, general acceptability, and texture using a nine-point hedonic scale (1, dislike-extremely to 9 , like-extremely).

\section{6) Data Analysis}

This experiment was conducted with two measurements. The significant effects of chitosan coating on the quality of red snapper were measured chemically and microbiologically. The data were subjected to analysis of variance by employing excel (microsoft). The statistical significance of differences between mean values was set at $\mathrm{P} \leq 0.05$ with Duncan test.

\section{RESULT AND DISCUSSION}

\section{1) Microbiological Analysis}

The raw material used in this study had the medium initial total viable count (TVC) (Table 1). It was $4.15 \log \mathrm{CFU} / \mathrm{g}$ which indicated that the freshness of the fish was reduced. This condition was due to the marine fish was ussually caught and transported to the market without proper handling. The increasing of TVC in the red snapper coated with chitosan was higher compared to control (1\% acetic acid). This finding was different with study done in other study [9] which applied chitosan on Pangasius pangasius fillet under chilling condition. They found that the total plate count of the pangasius fillets with the addition of chitosan were not exceeded log $5 \mathrm{CFU} / \mathrm{g}$ up until 9 days for $1 \%$ chitosan and 11 days for 2 and 3\% chitosan. The other study showed that application of $1 \%(\mathrm{w} / \mathrm{v})$ of chitosan on smoked milk fish at room temperature retained the microbiological quality up to seven days [13]. However, based on starting point of the application of chitosan was $\log 4 \mathrm{CFU} / \mathrm{g}$, both result this study and Damayanti [9] were able to maintain the microbiological quality up until three days. This study indicated that the initial microbiological quality of the fish will affect the storage of the fish.

Antimicrobial activity of chitosan affected by degree of polymeration therefore, the $\mathrm{pH}$ of the solution will affect the activity of chitosan. The $\mathrm{pH}$ of the fish of this study (higher than 6) maybe reduce the polymeration of chitosan on the fish matric [10]. In addition, particle size of the chitosan also affect the activity of antimicrobial of chitosan.

Several possibilities have been described as the mode of action for chitosan, from binding to bacterial DNA which leads to inhibition of mRNA, to interaction with surface molecules. The ability of chitosan to bind DNA was commonly investigated for gene delivery, but the contribution of such ability in antimicrobial activity is unclear because chitosan would not reach a target in the cytoplasm [10].

Table 1. Total viable count of red snapper coated with chitosan during chilling storage

\begin{tabular}{cccc}
\hline Storage time & \multicolumn{3}{c}{ Log CFU/g } \\
\cline { 2 - 4 } & $\mathbf{0 \%}$ & $\mathbf{1 \%}$ & $\mathbf{2 \%}$ \\
\hline 0 day & 4.15 & 4.15 & 4.15 \\
3 day & 5.66 & 6.17 & 6.54 \\
6 day & 7.95 & 7.95 & 7.95 \\
9 day & 8.95 & 10.03 & 9.78 \\
\hline
\end{tabular}

\section{2) $p H$ and TVB-N}

The $\mathrm{pH}$ value of red snapper with and without application of chitosan during storage was showed in Table 2 . The $\mathrm{pH}$ values of all samples were relatively constant, but the decreasing level of $\mathrm{pH}$ was exhibited on treatment $0 \%$ chitosan. Similar result was reportedby other study [6]. The initial reduce of $\mathrm{pH}$ value may be due to disolution of carbon dioxide from fish to the solution, while the increasing of $\mathrm{pH}$ is mainly due to production of volatile basic nitrogen. High $\mathrm{pH}$ value may affect the amino acid charge of the fish flesh that increases the possibility of microbes to degrade the amino acid on the flesh. The degradation of the fish protein produces volatile base that improve the $\mathrm{pH}$ of sample during storage [10].

Table 2. $\mathrm{pH}$ value of red snapper with and without chitosan coating during chilling storage

\begin{tabular}{lccc}
\hline Storage time & \multicolumn{3}{c}{$\mathbf{p H}$} \\
\cline { 2 - 4 } & $\mathbf{0 \%}$ & $\mathbf{1 \%}$ & $\mathbf{2 \%}$ \\
\hline
\end{tabular}




\begin{tabular}{llll}
\hline & & & \\
\hline day & 7.47 & 7.47 & 7.47 \\
6 day & 6.66 & 7.06 & 7.39 \\
9 day & 6.70 & 7.02 & 6.80 \\
\hline
\end{tabular}

Total volatile basic nitrogen (TVB-N) content of fish flesh during storage with and without chitosan coating showed in Table 3. TVB-N mainly consist ofammonia and amines which widely used as an indicator of fish deterioration. The increasing of TVB-N wasrelated to the increase of microbial activity and indigenous enzyme that hydrolyzed the protein of the fish [6]. In addition, TVBN value indicated the freshness of the sample [11]. The higher TVBN value showed the lower the quality of the fish. The treshold of acceptable level of TVB-N was $35-40 \mathrm{mg}$ TVB-N/100 $\mathrm{g}$ of samples [12].

Table 3. Total volatile basic nitrogen of snapper with and without chitosan coating during chilling storage

\begin{tabular}{cccc}
\hline Storage time & \multicolumn{3}{c}{ mg TVB-N/100 g sample } \\
\cline { 2 - 4 } & $\mathbf{0 \%}$ & $\mathbf{1 \%}$ & $\mathbf{2 \%}$ \\
\hline 0 day & 2.68 & 2.68 & 2.68 \\
3 day & 2.68 & 5.36 & 7.16 \\
6 day & 6.68 & 9.36 & 11.16 \\
9 day & 14.36 & 16.12 & 15.16 \\
\hline
\end{tabular}

Based on Table 3, the application of chitosan inhibited the production of TVB-N. This result was in accordance with research in other research [6].The TVB-N content of fish with and without treatment of chitosan was under acceptable level which indicated that the spoilage inhibited with the addition of acetic acid.

\section{3) Sensory Evaluation}

The fish samples sensory qualities were evaluated based on colour, texture, odour, flavour, and general acceptability based on 9 hedonic scale (9 extremely like, 1 extremely dislike).

Table 4. Overal sensory quality of fish (coated and uncoated of chitosan) during chilling storage

\begin{tabular}{lllll}
\hline Storage time & \multicolumn{3}{c}{ Overall acceptance score } \\
\cline { 2 - 4 } & $\mathbf{0 \%}$ & $\mathbf{1 \%}$ & $\mathbf{2 \%}$ \\
\hline \hline 176
\end{tabular}

\begin{tabular}{llll}
\hline 0 day & 6.70 & 6.70 & 6.70 \\
3 day & 6.22 & 6.18 & 6.22 \\
6 day & 3.78 & 5.30 & 4.74 \\
9 day & 2.46 & 3.00 & 3.46 \\
\hline
\end{tabular}

Acceptable level of sensory quality of consumable fish was 4 [6]. Therefore, the treatment of $1 \%$ and $2 \%$ of chitosan were kept the sensory quality of the red snapper up until 6 days. The spoilage process of the fish produces off odourand rejected by the consumer. The prolonged of sensory qualities of the red snapper in this study may due to the activity of chitosan, i.e. antimicrobial, antioxidant and oxygen barrier.

\section{CONCLUSION}

This study indicated that the application of chitosan coating can prolong the shelf life of red snapper until six days under chilling storage. Coating of $1 \%$ chitosan was the most effective concentration to prolong the shelflifeof red snapper. However, application of chitosan as preservative agent of fresh red snapper was less effective on low quality raw materials, it showed by the TVC, $\mathrm{pH}$, and TVBN value of this study. Therefore, the application of chitosan as coating agent on different raw material quality is needed.

\section{REFERENCES}

[1] L. Zhang, , Y. Luo, S. Hu, \&H.Shen, "Effects of chitosan coatings enriched with different antioxidants on preservation of grass carp (Ctenopharyngodonidellus) during cold storage," Journal of aquatic food product technology, Vol. 21, no. 5, hal. 508-518. Juni 2012

[2] B. Solo-de-Zaldívar, C.A. Tovar, A.J. Borderías, dan B. Herranz, "Pasteurization and chilled storage of restructured fish muscle products based on glucomannan gelation," Food Hydrocolloids Vol. 43, Hal. 418-426. Januari 2015 
[3] K.M. Xavier, N. Kannuchamy, A.K. Balange, M.K. Chouksey, dan V. Gudipati,"Functionality of chitosan in batter formulations for coating of fish sticks: Effect on physicochemical quality," Carbohydrate polymers Vol. 169 Hal. 433-440. Agustus 2017.

[4] G.U.O. Tsai, W.H. Su, H.C. Chen, dan C.L. Pan, "Antimicrobial activity of shrimp chitin and chitosan from different treatments," Fisheries science Vol. 68, no. 1 Hal. 170-177, Januari 2002.

[5] R. Cao, C.H. Xue, dan Q. Liu, "Changes in microbial flora of Pacific oysters (Crassostreagigas) during refrigerated storage and its shelf-life extension by chitosan," International Journal of Food Microbiology, Vol. 131, no. 2-3, Hal. 272-276, Mei 2009.

[6] W. Fan, J. Sun, Y. Chen, J. Qiu, Y. Zhang, dan Y. Chi, "Effects of chitosan coating on quality and shelf life of silver carp during frozen storage," Food Chemistry Vol. 115, no. 1, Hal. 66-70, Juli 2009.

[7] AOAC, "Official methods of analysis (17th ed.)," Washington, DC

[8] W. Vyncke, "Comparison of the official EC method for the determination of total volatile bases in fish with routine methods," Archiv fur lebensmittelhygiene, Vol. 47, Hal. 110111, September 1996.

[9] W. Damayanti, E. Rochima, dan Z. Hasan, "Application of Chitosan as Antibacterial for Pangasius Fillet at Low Temperature Storage," JurnalPengolahan Hasil Perikanan Indonesia, Vol. 19, no. 3, Hal. 321-328. Januari 2017.

[10] Z. Ma,A. Garrido-Maestu, dan K.C. Jeong, "Application, mode of action, and in vivo activity of chitosan and its micro-and nanoparticles as antimicrobial agents: A review," Carbohydrate polymers, Vol. 176, Hal. 257-265, November 2017.

[11] E.J. Choi, H.W. Park, Y.B. Chung, S.H. Park, J.S. Kim, dan H.H. Chun, "Effect of tempering methods on quality changes of pork loin frozen by cryogenic immersion," Meat Science, Vol. 124, Hal. 69-76, Februari 2017.

[12] J.J. Connell, "Methods of assessing and selecting for quality," Control of Fish Quality, Vol. 2, Januari 1990.

[13] H. Pramono, "Application of Chitosan to Prolong the Shelf Life of Smoked Milk Fish (ChanosChanos) in Room Temperature Storage," Journal of Marine and Coastal Science Vol.6, No. 2, Juni 2017. 